\title{
NIH faces plans to privatize clinical centre
}

Washington. US health department officials are considering plans to privatize all or part of National Institutes of Health (NIH) Clinical Center, the centrepiece of the NIH intramural research programme.

The privatization plan, which would involve transferring responsibility for the centre's functions to private contractors, has originated in the office of Philip Lee, the assistant secretary for health. It is one of a number of proposals being considered by Donna Shalala, the secretary of health and human services.

Suggestions of different ways of reducing the number of employees are seen in Shalala's department as a contribution towards President Bill Clinton's "reinventing government" initiative. But the plan has caused widespread alarm at the NIH campus at Bethesda, Maryland, where the Clinical Center employs 2,000 of its own staff, and also houses a further 4,000 individuals from the various NIH institutes.

Helen Smits, the deputy administrator of the Health Care Financing Administration, who has been asked by Shalala to assess options for privatization at the Clinical Center, visited the campus last week to begin talks with representatives of management and staff.

According to John Gallin, director of the centre, Smits indicated after the first round of meetings that she did not favour privatization of the entire operation. "We were impressed by her flexibility," Gallin says.

At the meetings, Smits was told of the obstacles that will inevitably confront even a partial privatization of the Clinical Centre. One is that attempts to contract out either of the two most obvious service functions at the centre - cleaning and catering - would leave the rest of the centre exposed to legal challenges over the under-representation of black employees.

The contracting out of work by laboratory technicians, on the other hand, could create different problems if the staff involved chose to exercise their right to stay in government service by moving from the Clinical Center to other parts of NIH, as in doing so they could displace more junior staff from their jobs.

NIH managers have been trying to persuade Smits that the centre could most effectively increase its efficiency in areas such as purchasing where, they suggested, government-run hospitals could cooperate in order to cut costs. Smits, who has two months to report back to Shalala, has set up a panel of experts from both inside and outside NIH in order to help her explore privatization options.

The plan to privatize services at the Clinical Center is separate from impending plans to replace the ageing, main clinical centre building with a new 250-bed hospital, at an estimated cost of $\$ 380$ million. Gallin and other officials say that the rebuilding plan is still on track - even though there is no extra money in NIH budget projections to pay for it.

The institutes' budget for the 1996 financial year, now being considered by Congress, includes $\$ 26$ million for the design of the new hospital. The 1997 budget is expected to include provision for its construction, but it has not been determined which programmes should be cut to enable this. Gallin says the $\mathrm{NIH}$ is exploring "other approaches" to finding money for the new hospital, but that talk of private funding would be "speculation" at this stage.

The privatization proposal is part of a broad effort by the Clinton administration to cut staffing levels across the federal government. But NIH officials are worried that, in this case, the administration may proceed in order to meet its staffing targets - even if

\section{New 'security' role urged for science}

Washington. Social collapse in the poor nations of the world and global environmental degradation are now the principal threats to US national security with which science must contend, Vice President Al Gore told a high-powered forum of scientists in Washington last week.

Gore described the use of science and technology to build better weapons to defend the US from external threats as an "entirely inadequate" response to national security problems. "We need to ask how science and technology can assist us in coping with new challenges which often feature a multifactorial assault on society," he said.

Gore was addressing the $\mathbf{4 0 0}$ science and technology experts invited

to a meeting at the Gore: seeking more National Academy support for policies. of Sciences to help

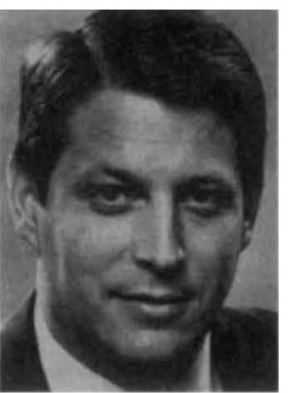

the Clinton administration draft a new policy document on the role of science and technology in national security.

Like last summer's basic research policy document Science in the National Interest (see Nature 370, 401; 1994), the document is supposed to explain the principles for the administration's support of science.

Critics contend that such statements, intended for a broad audience and lacking specific proposals on the allocation of money, serve little useful purpose. But no money is likely to be saved. A memorandum last week from Shalala to all department staff pointedly failed to deny that the privatization of the Clinical Center was under consideration.

The centre is a critical component of the NIH's $\$ 10$ billion biomedical research programme, accounting at any given time for 40 per cent of all hospital beds used for patients taking part in clinical research. Its supporters say the role of the centre will become even more critical in coming years, as financial pressure makes it harder for medical centres outside NIH to find beds for patients in clinical trials.

But the administration's proposal for radical change at the centre may be only the first of a series of major upheavals at NIH as, after years of strong growth, it comes to terms with a budget that is unlikely to grow fast enough to cover inflation.

Colin Macilwain

Jane Wales, associate director of national security at the White House Office of Science and Technology Policy (OSTP) and organizer of the forum, said that both the meeting and the document would help OSTP to "determine if it was successfully supporting the President's national security strategy".

The policy document is likely to reflect the administration's broad view of national security, Wales says, embracing the need for sustainable economic development in developing countries and a response to environmental threats, as well as military preparedness.

This may, however, bring the administration into conflict with the Republican majority in Congress, which is sceptical about sustainable development and continues to equate national security with military strength.

Senator Sam Nunn (Democrat, Georgia) and William Perry, the defence secretary, used the forum to call for more support from US universities in trying to find new tasks for Russian scientists formerly engaged in nuclear weapons research. "We need every research university in the US to have at least one or two [collaborative projects] on board," said Nunn.

Charles Curtis, under-secretary at the Department of Energy, said science and technology could help in attempts to counter internal security threats, such as last month's chemical attack on the Tokyo underground railway system. But Joshua Lederberg, the Nobel prizewinning geneticist, warned that deploying technology to such ends would be difficult.

C.M. 